\title{
Partial characterization of nif genes from the bacterium Azospirillum amazonense
}

D.P. Potrich ${ }^{1}$,
L.M.P. Passaglia ${ }^{1,3}$
and I.S. Schrank ${ }^{1,2}$
${ }^{1}$ Centro de Biotecnologia, and Departamentos de

${ }^{2}$ Biologia Molecular e Biotecnologia and ${ }^{3} \mathrm{Genética,}$

Universidade Federal do Rio Grande do Sul, Porto Alegre, RS, Brasil

\section{Correspondence \\ I.S. Schrank \\ Centro de Biotecnologia \\ Departamento de Biologia Molecular \\ e Biotecnologia \\ Av. Bento Gonçalves, 9500 \\ Caixa Postal 15005 \\ 91591-970 Porto Alegre, RS \\ Brasil \\ Research supported by FAPERGS \\ and CNPq. D.P. Potrich is the \\ recipient of a CAPES fellowship.}

Received O ctober 26, 2000

Accepted June 18, 2001

\section{Abstract}

Azospirillum amazonense revealed genomic organization patterns of the nitrogen fixation genes similar to those of the distantly related species $A$. brasilense. Our work suggests that $A$. brasilense nifHDK, nifENX, fix $A B C$ operons and nifA and $g \ln B$ genes may be structurally homologous to the counterpart genes of $A$. amazonense. This is the first analysis revealing homology between $A$. brasilense nif genes and the $A$. amazonense genome. Sequence analysis of PCR amplification products revealed similarities between the amino acid sequences of the highly conserved nifD and $g \ln B$ genes of $A$. amazonense and related genes of $A$. brasilense and other bacteria. However, the $A$. amazonense non-coding regions (the upstream activator sequence region and the region between the nifH and nifD genes) differed from related regions of $A$. brasilense even in nitrogenase structural genes which are highly conserved among diazotrophic bacteria. The feasibility of the $16 \mathrm{~S}$ ribosomal RNA gene-based PCR system for specific detection of $A$. amazonense was shown. Our results indicate that the PCR primers for $16 \mathrm{~S}$ rDNA defined in this article are highly specific to $A$. amazonense and can distinguish this species from A. brasilense.

\section{Introduction}

Bacteria belonging to the genus Azospirillum are found associated with forage grasses, cereals and agriculturally important crops from various geographical origins. This genus consists of seven species, A. lipoferum, A. brasilense, A. amazonense, A. halopraeferens, A. irakense (1), A. largomobile (2), and A. doebereinerae (Eckert B, Baller-Weber O, Kirchhof G, Halbritter A, Stoffels M and Hartmann A, unpublished results, and GenBank accession number AJ238576). Worldwide inoculation experiments using a variety of crops have shown that Azospiril-
Key words

- Azospirillum amazonense

- nif genes

- glnB

- 16S rDNA lum species can contribute to the nitrogen economy $(3,4)$. In addition, experiments with sugarcane and other crops suggest either a synergistic or an additive effect when $A$. amazonense is used in combination with other

A. amazonense differs in several important characteristics when compared to other Azospirillum species. Its nitrogenase activity has lower oxygen tolerance, its ability to use sucrose as carbon source is different, and the most remarkable difference is its sensitivity to alkaline $\mathrm{pH}(6)$. The genetic relationship existing between $A$. amazonense and other Azospirillum species was analyzed by $16 \mathrm{~S}$ diazotrophics as inoculant (5). 
rDNA restriction fragment length polymorphism (7). The phylogenetic analysis, based on $16 \mathrm{~S}$ rDNA sequences, confirmed that $A$. amazonense and A. irakense form one cluster and that the closely related species $A$. brasilense and A. lipoferum form a second cluster together with $A$. halopraeferens (8).

During the last few years, nitrogen fixation (nif) genes have been isolated from a variety of diazotrophic organisms. In $A$. brasilense a DNA fragment of 25,100 bp encompassing the nif region was shown to contain the nifHDKORFIY (9), the ORF2nifUSVORF4 (10), an mcp-like gene, the nifENXORF3,5, fdxAnifQ, and the fixABCX (Gross J, Vedoy $\mathrm{C}$ and Schrank IS, unpublished results) transcriptional units. However, to date, few genes were isolated from $A$. amazonense and none of them could be related to the biological nitrogen fixation process.

We report here the application of PCR and Southern hybridization to characterize some of the nif genes from A. amazonense. We have also analyzed the amplification products from two conserved regions within the nifD and $g \ln B$ genes. Moreover, we have developed primers that specifically amplify A. amazonense DNA and allow us to distinguish between this species and A. brasilense.

\section{Material and Methods}

\section{Bacterial strains and growth conditions}

A. brasilense Sp7 (ATCC29145) and A. amazonense (ATCC35119) were grown on NFB and LGI minimal media, respectively, as previously described $(6,11)$.

\section{DNA manipulation and sequence analysis}

All DNA manipulations were performed using standard techniques (12) and instructions provided by suppliers of material, enzymes or reagents. Total DNA extraction of A. amazonense was performed as previously described (13) and Southern blot analysis was performed with the ECL Direct Nucleic Acid Labeling and Detection Systems (Amersham Pharmacia Biotech, Uppsala, Sweden).
The nucleotide sequence determination was performed by the chain-termination method of Sanger et al. (14) using ${ }^{33} \mathrm{P}-\mathrm{dNTP}$ and the ThermoSequenase radiolabeled terminator cycle sequencing kit (Amersham). The PCR products were purified using the GFX PCR kit from Amersham. Analysis of DNA sequences and comparison with nucleotide and deduced protein sequences from other organisms were performed using the GCG (Wisconsin Package Version 9.0, Genetics Computer Group, Madison, WI, USA) computer programs (licensed to CENARGENEMBRAPA, Brasília, DF, Brazil).

\section{Amplification conditions}

PCR amplification of the target sequences was performed using a DNA thermal cycler (MJ Research, Waltham, MA, USA). The PCR mixture contained the reaction buffer (50 mM KCl, 10 mM Tris- $\mathrm{HCl}, \mathrm{pH} 8.3,2.5$ $\mathrm{mM} \mathrm{MgCl} 2$ ), $200 \mu \mathrm{M}$ of each dNTP, $30 \mathrm{pmol}$ of each primer, $1 \mathrm{U}$ of Taq polymerase (CenBiot enzymes, Centro de Biotecnologia, UFRGS, Porto Alegre, RS, Brazil), template DNA, and distilled water to a final concentration of $25 \mu \mathrm{l}$. The reaction mixture was subjected to PCR under the following conditions: heat denaturation at $94^{\circ} \mathrm{C}$ for $5 \mathrm{~min}$ and then an additional 35 cycles with heat denaturation at $94^{\circ} \mathrm{C}$ for $30 \mathrm{~s}$, annealing (at a temperature defined for each set of primers, see Table 2) for $30 \mathrm{~s}$, and DNA extension at $72^{\circ} \mathrm{C}$ for $30 \mathrm{~s}$. After the last cycle, samples were maintained at annealing temperature for $5 \mathrm{~min}$ followed by $72^{\circ} \mathrm{C}$ for $10 \mathrm{~min}$. PCR products were analyzed by gel electrophoresis (12). Primers listed in Table 2 were purchased from Oligo ETC. \& Oligo Therapeutics Inc. (Wilsonville, OR, USA).

\section{Results and Discussion}

\section{A. amazonense nif genes: hybridization and PCR}

In order to understand the molecular organization of some of the nif genes from $A$. amazonense and to establish their relationship with the well-known nif genes from $A$. 
brasilense, we used two different approaches. Initially, DNA fragments from different nif operons already characterized in A. brasilense were used in Southern blot hybridization to analyze the relatedness between the two Azospirillum species. The hybridization patterns of A. amazonense DNA are shown in Figure 1. The nif structural genes from $A$. amazonense are localized in a $6.5-\mathrm{kb}$ EcoRI DNA fragment (Figure 1A) as previously found for A. brasilense genome (13). In A. brasilense and other diazotrophic bacteria the nifHDK genes are organized in a single transcriptional unit (9). To determine whether the $A$. amazonense nif genes are clustered in a similar manner as found in A. brasilense and other nitrogen-fixing organisms, we used sequences from nif genes (Table 1) from $A$. brasilense as DNA hybridization probes. Three different probes, which consist of the entire nifHDK operon (data not shown), the nifH gene alone (data not shown) from $A$. brasilense, and a region of the nifD gene (Table 1) from A. amazonense, showed homology with the same DNA fragment from A. amazonense (Figure 1A, lane 1E). This result suggests that the region comprising a 6.5-kb EcoRI DNA fragment probably contains the nifHD homologous in A. amazon- ense and that the genes are organized in a single operon. Nevertheless, the hybridization pattern of the nifD gene amplified from $A$. amazonense revealed a different restriction pattern when $A$. amazonense and $A$. brasilense total DNA was digested with PstI and SalI restriction enzymes (Figure 1A, lanes $1 \mathrm{P}$ and $1 \mathrm{~S}$ ). A hybridization signal specific to SalI DNA fragments was obtained when A. amazonense total DNA was hybridized with $A$. brasilense nifENX and fix $A B C$ probes, respectively (Figure $1 \mathrm{~B}$, lane 1 and Figure 1C, lane 1).

In order to understand the nature of the $A$. amazonense genes that regulate nitrogen fixation we have isolated and characterized the nif $A$ and $g \ln B$ genes, which are responsible for the regulation of other nif genes and operons in A. brasilense $(15,16)$. The presence of genes homologous to $g \ln B$ and nifA was detected by hybridization of $A$. amazonense DNA with two different probes (Table 1). The entire nifA gene from $A$. brasilense is present within a $2.5-\mathrm{kb}$ SalI DNA fragment (15). Heterologous hybridization revealed that the nifA homologue in A. amazonense is also found in a SalI DNA fragment of approximately $3 \mathrm{~kb}$ (Figure 1D, lane 1).

The $g \ln B$ homologous gene was local-
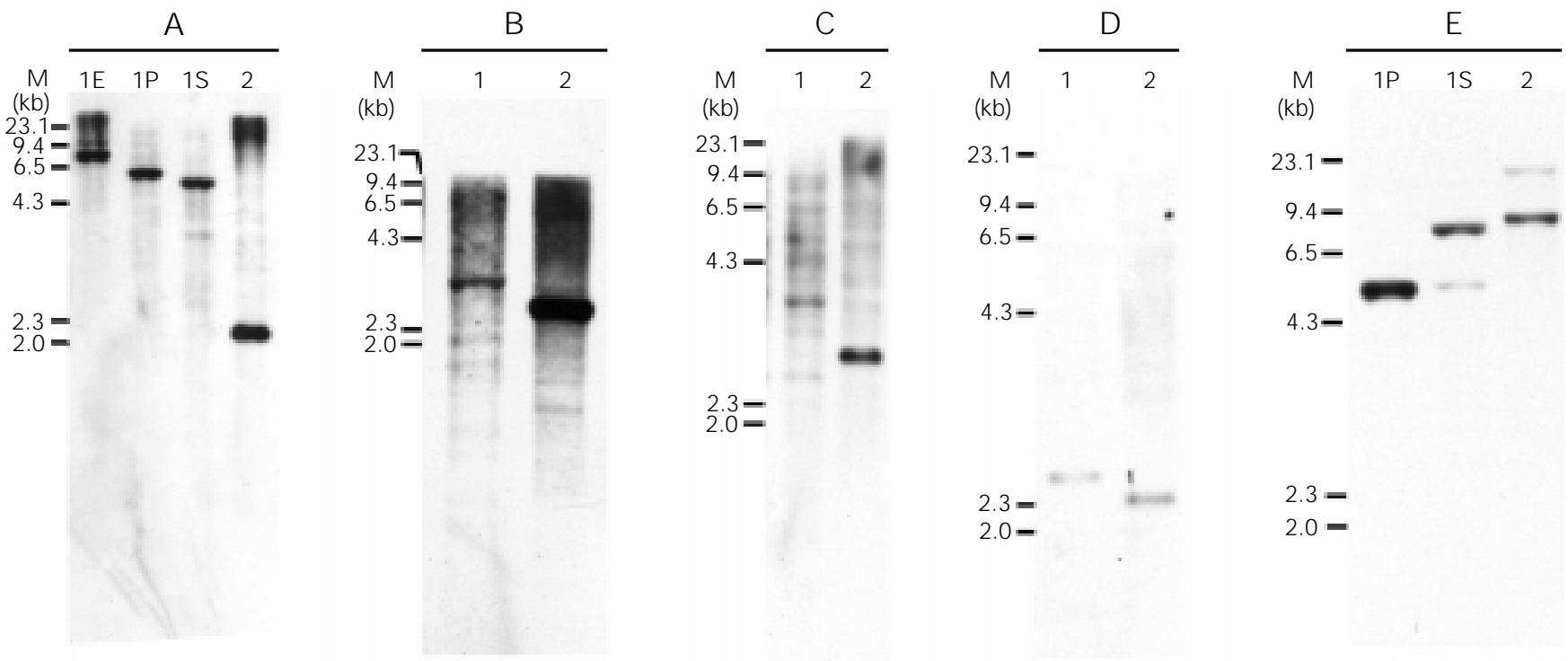

Figure 1. Hybridization pattern of Azospirillum amazonense total DNA with EcoRI (1E), Pstl (1P), and Sall (1S) in A, Sall in B, C and D, and Pstl (1P) and Sall (1S) in E with the following probes: nifD in panel A; nifEN in panel B; fixABC in panel C; nifA in panel D, and glnB in panel E. Lane 2 represents $A$. brasilense total DNA digested with Pstl in A, C and E, or Sall in B and D. Lane M contains $\lambda$ HindllI as molecular marker. 
ized within a 4.5-kb PstI DNA fragment from $A$. amazonense (Figure 1E, lane 1P). Faint hybridization signals were detected in A. amazonense total DNA and also with PstI-digested A. brasilense total DNA (Figure $1 \mathrm{E}$, lane 2). Genes homologous to $g \ln B$ have been found in A. brasilense, Herbaspirillum seropedicae and other bacteria, suggesting the presence of two copies of $g \ln B$ like genes in these organisms $(17,18)$. Since no PstI restriction site was found within $g \ln B$ or $g \ln Z$ genes from $A$. brasilense or in

Table 1. Plasmids and probes.

\begin{tabular}{|c|c|c|}
\hline Probe & Characteristics & Reference \\
\hline nifHDK & $\begin{array}{l}\text { 6.5-kb EcoRI A. brasilense } \\
\text { DNA fragment (nifHDKORF1Y operon) }\end{array}$ & 9 \\
\hline nifH & $\begin{array}{l}\text { 2.8-kb EcoRI/Pstl A. brasilense } \\
\text { DNA fragment (nifHDKORF1Y operon) }\end{array}$ & 9 \\
\hline nifD & A. amazonense PCR fragment & Present study \\
\hline$g \ln B / P_{\| I}$ & A. amazonense PCR fragment & Present study \\
\hline nifA & $\begin{array}{l}\text { 2.5-kb Sall A. brasilense } \\
\text { DNA fragment (nifA gene) }\end{array}$ & Pedrosa F (with permission) \\
\hline nifEN & $\begin{array}{l}\text { 2.2-kb EcoRI/HindIII A. brasilense } \\
\text { DNA fragment (nifENX operon) }\end{array}$ & $\begin{array}{l}\text { Potrich D, Bressel T, } \\
\text { Schrank IS and Passaglia L } \\
\text { (unpublished results) }\end{array}$ \\
\hline fixABC & $\begin{array}{l}\text { 3.0-kb Pstl A. brasilense } \\
\text { DNA fragment (fixABCX operon) }\end{array}$ & $\begin{array}{l}\text { Gross J , Vedoy C and } \\
\text { Schrank IS (unpublished results) }\end{array}$ \\
\hline
\end{tabular}

Table 2. Oligonucleotide primers.

\begin{tabular}{llccc}
\hline Primer & \multicolumn{1}{c}{ Oligonucleotide sequence } & $\begin{array}{c}\text { Length } \\
(\mathrm{bp})\end{array}$ & $\begin{array}{c}\text { Amplification } \\
\text { size }(\mathrm{bp})\end{array}$ & $\begin{array}{c}\text { Annealing } \\
\text { temperature }\end{array}$ \\
\hline UAS1 & 5'CCTGACGCTGGCTCTGACGCTGG & 23 & 200 & $52^{\circ} \mathrm{C}$ \\
UAS2 & 5'CGCGAACTGGCACGGGGGATGCA & 23 & & \\
IGR-up & 5'ATCCCGACCCCGTCACGATG & 21 & 310 & $52^{\circ} \mathrm{C}$ \\
IGR-do & 5'CTTCTCGGGATACGCTTC & 18 & & \\
nifD-up & 5'ATCATCGGTGACTACAAC & 18 & 710 & $52^{\circ} \mathrm{C}$ \\
nifD-do & 5'ATCCATGTCGCGGCGAA & 17 & & \\
nifA-up & 5'CGCGGCGAGAGCGGCACC & 18 & na & $42^{\circ} \mathrm{C}$ \\
nifA-do & 5'GCGCCGTTCGCGCAGCGG & 18 & & \\
glnB-up & 5'GCCATCATTAAGCCGTTCAA & 20 & 250 & $56^{\circ} \mathrm{C}$ \\
glnB-do & 5'AAGATCTTGCCGTCGCCGAT & 20 & & \\
16S-up & 5'TGATGGTTGTGAGACTGTCAG & 22 & 400 & $52^{\circ} \mathrm{C}$ \\
16S-do & 5'ATTCACGCCTGACTTAAACA & 21 & &
\end{tabular}

UAS = upstream activator sequences; IGR = intergenic region; na = no amplification; do $=$ downstream; up $=$ upstream. the $g \ln B$ gene from $A$. amazonense, the presence of two hybridization fragments in both strains may represent similarity between the probe and the two $g \ln B$-like genes.

The results presented here are the first to reveal homology between A. brasilense nif genes and $A$. amazonense total DNA. Taken together, these results suggest that the nifHDK, nifENX and fixABC operons and the nifA and $g \ln B$ genes may be structurally homologous to $A$. amazonense counterpart genes.

The second approach to the understanding of the nature of nitrogen fixation in $A$. amazonense was based on PCR amplification of regions within the niflfix genes. Several primers were selected from the sequences of the niflfix genes from A. brasilense. The primers listed in Table 2 represent, except for nifA, those that revealed positive and conclusive results after PCR amplification and DNA sequencing. Three sets of primers were designed from regions within the $A$. brasilense nifHDK operon. The promoter region of this operon shows two overlapping upstream activator sequences (UAS) as the only potential NifA-binding sites (19). To date this organization seems to be unique to A. brasilense and may be an atypical NifAbinding site interacting with two dimers of NifA, as proposed to occur in other nif promoters (20). UAS primers define a region of approximately $200 \mathrm{bp}$ in the nifH promoter sequence encompassing the two overlapping UAS. The second pair of IGR primers is derived from the intergenic region between nifH and nifD and amplifies a 310-bp region. In $A$. brasilense three inverted repeat structures have been found downstream from the nifH stop codon (9). Transcription analysis revealed the presence of one $1.1-\mathrm{kb}$ transcript corresponding to the nifH gene (21). The nifD primer pair is specific for a 710-bp region of the nifD gene containing a highly conserved amino acid sequence and a serine residue which is present only in the nifD gene of A. brasilense (9).

Amplification of $A$. amazonense DNA with the above selected primers (Table 2) resulted in fragments of the predicted size (Figure 2A,B,C). All three amplified DNA 
fragments were used to probe total A. amazonense DNA, revealing homology with the same EcoRI fragment encompassing the nifHD genes (Figure 1A). To further characterize the PCR products, all DNA fragments were purified and sequenced. The sequences for the UAS and IGR products showed very little similarity to the A. brasilense counterparts (data not shown). Only the region amplified within the nifD gene is similar to other nifD gene sequences (discussed below). These results indicate that the A. amazonense non-coding regions described above differ from related $A$. brasilense regions even among nitrogenase structural genes which are highly conserved among diazotrophic bacteria.

A set of primers was designed (Table 2) from previously published sequences of nifA and $g \ln B$ genes from $A$. brasilense $(15,22)$. A PCR product of approximately $250 \mathrm{bp}$ was detected in A. amazonense DNA (Figure 2D, lane 1). This product hybridized with total $A$. amazonense DNA (Figure 1E, lanes 1P and $1 S$ ) and, after DNA sequencing, revealed homology with $\mathrm{P}_{\text {II }}$ proteins from different organisms (discussed below). Surprisingly, no amplification product was visualized when nifA target primers were applied to A. amazonense DNA although these primers were designed on the basis of a highly conserved region found among NifA proteins from A. brasilense, A. lipoferum and related bacteria. This unexpected result suggests that the $A$. amazonense nifA gene may have greater differences in DNA sequence than found among other nifA genes previously characterized.

\section{Amplification of A. amazonense 16S rDNA}

To overcome problems with misinterpretation of the PCR results, a PCR amplification system was developed to specifically detect A. amazonense. The 16S rRNA sequence from Azospirillum species was obtained from the GenBank database. Multiple sequence alignments to other $16 \mathrm{~S}$ rRNA gene sequences revealed one region of considerable sequence divergence from the closest relatives, as shown in Figure 3. Two primers (16S-up and 16S-do) were constructed, one based on the variable region and the other based on a lower sequence divergence region (Table 2). The PCR product generated with $A$. amazonense was 400 bp long (Figure $2 \mathrm{E}$, lane 2) and was confirmed by direct sequencing (Figure 3 ). No PCR product was detected when $A$. brasilense DNA was the template (Figure 2E, lane 3). Using this methodology we could specifically detect and differentiate DNA templates from these two Azospirillum species.

\section{Interspecies conservation of nif/gln genes}

A sequence comparison of the A. amazonense and $A$. brasilense nifD genes revealed a high degree of similarity at both the DNA and amino acid levels (Figure 4). One relevant difference between $A$. amazonense and $A$. brasilense NifD proteins is located at position 275 (relative to A. brasilense NifD sequence; 9). The A. brasilense nifD gene product contains a total of five cysteine residues, four of which are highly conserved

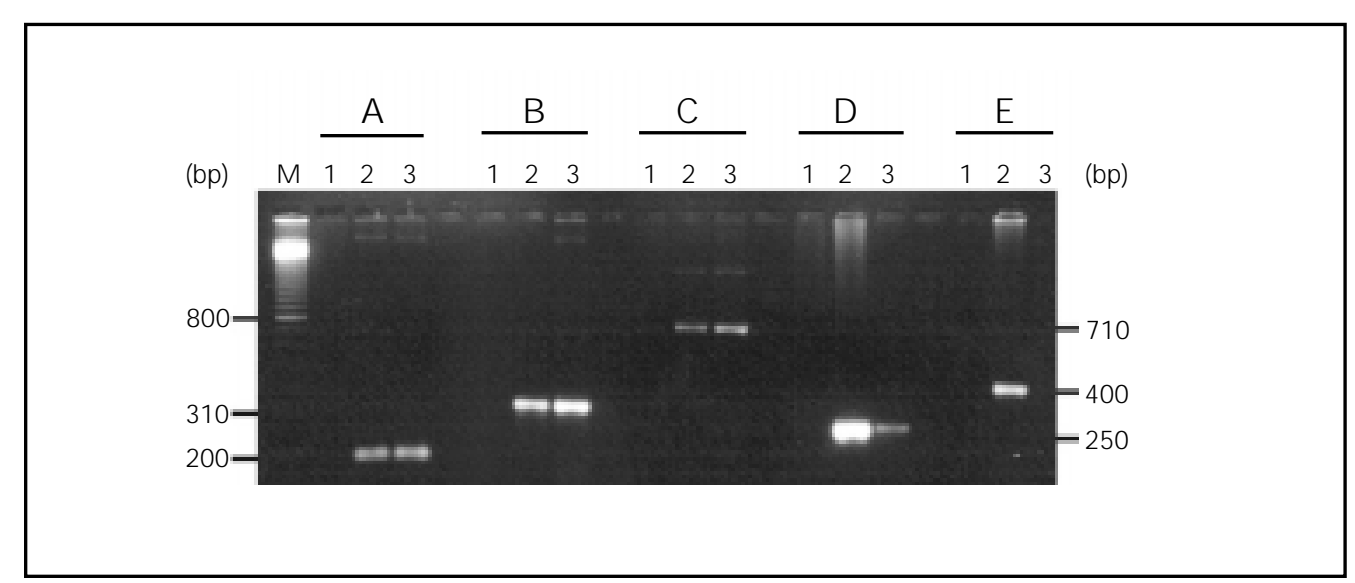

Figure 2. Specific PCR for amplification of nif genes from Azospirillum amazonense. Amplified products on $1.5 \%$ agarose gel were visualized with a UV transilluminator after ethidium bromide staining using the following primers: panel $A$, UAS; panel B, IGR; panel C, nifD; panel $D$, glnB, and panel $E$, rRNA from $A$. amazonense (lane 2) and $A$. brasilense (lane 3 ) total DNA. The negative control (lane 1) contains no template DNA in the reaction mixture. Lane M contains the 100-bp DNA ladder (Gibco/BRL). 

A.brasilense (sp7)
A.brasilense (apf94)
A. brasilense (edx)
A. amazonense (PCR)
A. amazonense (dan)
A. amazonense $\left(y^{2}\right)$
A. amazonense (2787)

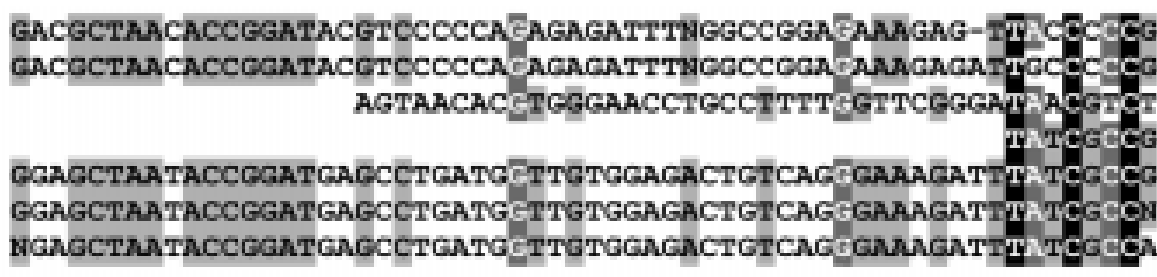

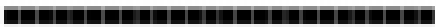

176

178

42

171

179

178

235

237

99

64

228

235

234

293

296

158

123

287

295

293

AATCEGTAGCTGGTCTKAGA GATHKA-

CAGCCACACTEGGACTEAGACACGGCCCAGAC

ChECCACACTEGERCTENENCACGECCCAGAC

352

A. amazonense (2787)

A.brasilense (ap7)

A.brasilense (spr94)

A.brasilense (cdr)

A. amazonense (PCR)

A. amazonense (dsm)

A. amazonense ( $\left.Y^{2}\right)$

A. amazonense (2787)

A.brasilense (ap7)

A.brasilense (spr94)

A.brasilense (cdr)

A. amazonense (PCR)

A. amazonense (Asm)

A. amazonense ( $\left.Y^{2}\right)$

A. amazonense (2787)

A.brasilense ( $\mathrm{p} 7$ )

A.brasilense (spf94)

A.brasilense (cdr)

A. amazonense (PCR)

A. amazonense (Asm)

$\lambda$. amazonense ( $\left.Y^{2}\right)$

A. amazonense (2787)
355

218

183

347

355

353

-TCTACGGGAGGCAGCAGTGEGGAATATTGGACAATEGGGGCAACCCTEATCCAGCAATC

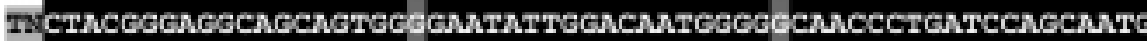
TCCTACGGGAGGCAGCAGTGGGGAATATTGGACAAT GGGGGCAACCCTCATCCAGCAATC TCCTACGGGAGGCAGCAGTGGGGATATTGGACAATEGGGGCAACCCTEATCCAGCAATS TCCTACGOCACOCACCAGTGCGCAATATTGCACAAT CGCOCCAACCCTCATCCAOCAATC TCCTACGGGAGGCAGCAGTGGTIAATATTGGACAATEGGETCAACCCTGATCCAGCAATV

CCGCGTARGTARTENGCCCITMGGGITGTMMECTC CCGCGTGAGTGARGAAGGCCTTAGGGTTGTAAAGCTC CCGCGTGAGTGATEAAGECCITMGGGTTGTAAAGCTC CCGCGTGAGTGATGAAGOCCTTAGGGTTGTAAAGCTC CCGCGTGAGTGAFGAAGGCCTTAGGGTTGTAAAGCTC CCGCGTGAGTGATENAGCCFTMGGGTTETAMGCTCCCGCGTGAGTGAFGAAGGCCFTHGGGFTGTAAAGCTC

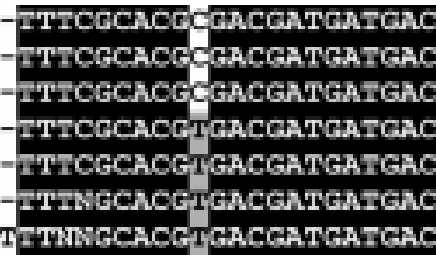

411

414

277

242

406

414

413

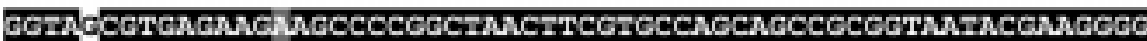
GGFAGCGTGAGAAGAAGCCCGGCTAACTTCGRGCCAGCAGCCGCGGTAATACGAAGGGC

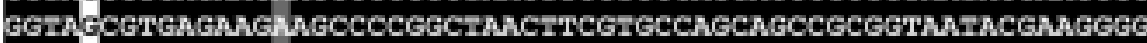

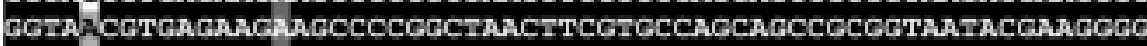
GGRA CGTGAGAAGAAGCCCCGGCRAACTTCGRGCCAGCAGCCGCGGTAATACGAAGGGE

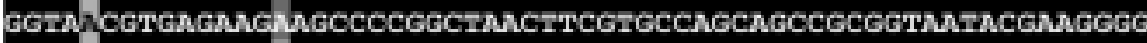
GGRA CGTGAGAAGCAGCCCCGGCRAACTTMNRGCCAGCAGCCGCGGTAATACCAAGGGC

471

474

337

302

466

474

473
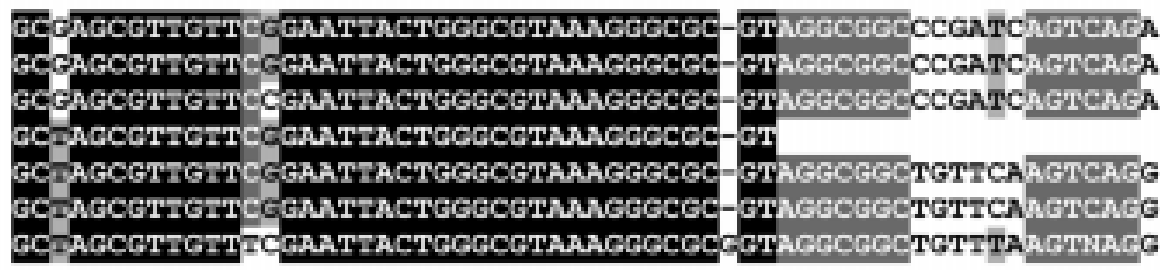

530

533

396

341

525

533

533 
Continued
A.brasilense (sp7)
A.brasilense (spf94)
A.brasilense (cdr)
A. amazonense (PCR)
A. amazonense (dsm)
A. amazonense ( $\left.y^{2}\right)$
A. amazonense (2787)

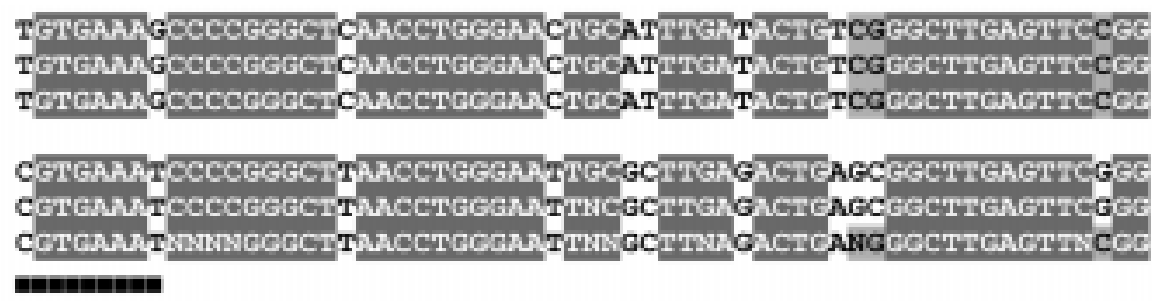

Figure 3. Multiple sequence alignment of the 16S rDNA genes from Azospirillum amazonense (GenBank accession Nos. X79735, Z29616, X79742) and the distantly related A. brasilense Sp7 (GenBank accession Nos. X79732, 79739, 79740). A. amazonense (PCR) represents the PCR DNA sequence obtained in the present study. The primers used here for the PCR amplification experiments are underlined. A black background indicates conserved residues in all aligned sequences, a dark grey background indicates conserved residues in at least $80 \%$ of the aligned sequences, and a light grey background indicates conserved residues in at least $60 \%$ of the aligned sequences. Multiple alignments were done with the PILEUP program, University of Wisconsin Genetics Computer Group, and the alignment editing was done using the GENDOC program considering the score table Dayhoff PAM $250(26,27)$.

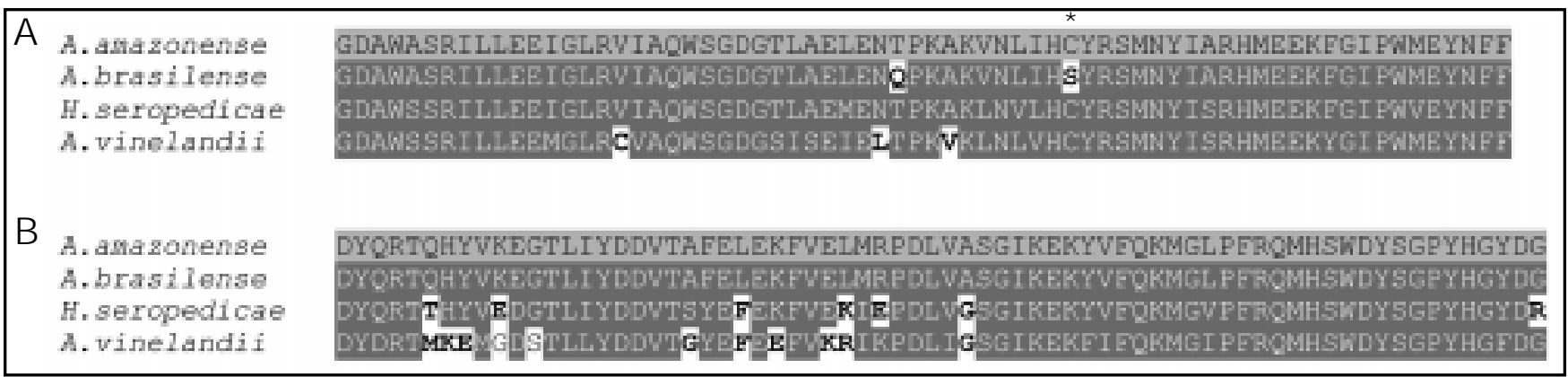

Figure 4. Azospirillum amazonense nifD protein partial sequence alignment with A. brasilense (GenBank accession No. M64344), Herbaspirillum seropedicae (GenBank accession No. Z54207) and A. vinelandii (GenBank accession No. M20568) NifD proteins. A grey background indicates similarity including the conserved amino acid substitutions while using the $A$. amazonense sequence as reference sequence. Amino acid-derived sequence from DNA sequencing obtained with primer nifD-up (A) and with primer nifD-do (B). The cysteine residue 275 is marked with an asterisk. Multiple alignments were done with the PILEUP program, University of Wisconsin Genetics Computer Group, and the alignment editing was done with the GENDOC program considering the Dayhoff PAM 250 score table $(26,27)$.

among the other nifD genes with respect to both positions and adjacent sequences (9). Of the five conserved cysteine residues proposed to act as ligands to the iron-clusters of dinitrogenase, the cysteine at position 275 is substituted by a serine on the A. brasilense predicted sequence (Figure 4) (9). The highly conserved nifD region amplified from $A$. amazonense shows a cysteine residue at position 275 (Figure 4), suggesting that the substitution observed in the A. brasilense nifD gene is not conserved among other Azospirillum species and appears to be unique among diazotrophic bacteria.

The regulation of nitrogen fixation in $A$. lipoferum and $A$. amazonense is less well understood than in A. brasilense. The regulation is controlled both transcriptionally and post-translationally in A. brasilense and $A$. lipoferum (23). In A. brasilense, the expression of the nifHDK operon is positively regulated by NifA. In this bacterium nifA is expressed under conditions both compatible and incompatible with nitrogen fixation. NifA activity is modulated by the $\mathrm{P}_{\mathrm{II}}$ protein (encoded by $g \ln B$ ), the intracellular signal transmitter, in response to the nitrogen status of the cell. The $g \ln B$ gene of A. lipoferum was isolated, but the $\mathrm{P}_{\mathrm{II}}$ protein has not yet been characterized (24). The isolation of part of the $g \ln B$ gene from $A$. amazonense is the first evidence that the nitrogen regulatory path- 

R. capsulatus
R. sphaeroides
A. amazonense
A. brasilense
R. rubrum
A. caulinodans
R. meliloti
B. japonicum
H. seropedicae
R. Capsulatus
R. sphaeroides
A. amazonense
A. brasilense
$R$. rubrum
A. caulinodans
R. meliloti
B. japonicum
H. seropedicae

Figure 5. Azospirillum amazonense glnB partial deduced amino acid sequence alignment with A. brasilense (GenBank accession No. X51499), Rhodobacter sphaeroides (GenBank accession No. AF032116), R. capsulatus (GenBank accession No. U25953), Rhodospirillum rubrum (GenBank accession No. X84158), Azorhizobium caulinodans (GenBank accession No. Y10213), Rhizobium meliloti (GenBank accession No. U50385), Bradyrhizobium japonicum (GenBank accession No. M26753), and Herbaspirillum seropedicae (GenBank accession No. U86073) P॥ proteins. A black background indicates conserved residues in all aligned sequences, a dark grey background indicates conserved residues in at least $80 \%$ of the aligned sequences, and a light grey background indicates conserved residues in at least $6 \%$ of the aligned sequences. Multiple alignments were done with the PILEUP program, University of Wisconsin Genetics Computer Group, and the alignment editing was done with the GENDOC program considering the Dayhoff PAM 250 score table $(26,27)$.

way of this microorganism may be similar to that of other Azospirillum species. The $\mathrm{P}_{\mathrm{II}}$ protein from A. amazonense revealed a high level of similarity when compared to $\mathrm{P}_{\mathrm{II}}$ from other diazotrophic bacteria (Figure 5).

The occurrence of duplicate copies of genes encoding $\mathrm{P}_{\mathrm{II}}$-like proteins now appears to be common among members of the $\alpha$ (Azospirillum) and $\gamma($ Klebsiella $)$ subdivisions of the Proteobacteria class. In A. brasilense, $\mathrm{P}_{\mathrm{II}}$ and $\mathrm{P}_{\mathrm{Z}}$ proteins are involved differently in nitrogen-dependent regulation of various physiological functions (25). The $\mathrm{P}_{\mathrm{II}}$ amino acid sequence is about $60 \%$ identical to that of $\mathrm{P}_{\mathrm{Z}}$ and could explain the detection of two hybridization signals in A. brasilense and $A$. amazonense Southern blots (Figure $1 \mathrm{E}$, lane $1 \mathrm{~S}$ and lane 2).

In this report, we present distinct lines of evidence showing that the nif gene organization and regulation in A. amazonense differ, in some aspects, from those of the best characterized $A$. brasilense. Although our results indicate the presence of counterparts of genes nifHDK, nifENX, fix $A B C$, nifA, and $g \ln B$ in $A$. amazonense, we found differences in restriction sites and non-coding sequences suggesting that the organization of these genes may differ from that of the related A. brasilense. These results support the suggestion by Fani et al. (8) that $A$. amazonense isolates may be members of a taxonomic cluster that is clearly distinct from the closely related $A$. brasilense and A. lipoferum species.

\section{Acknowledgments}

The authors thank J.I. Baldani for providing the bacterial strains, Dr. F. Pedrosa for provinding the nifA-containing plasmid, and A. Schrank and S.C. da Silva for a critical reading of this manuscript. 


\section{References}

1. Bashan Y \& Holguin G (1997). Azospirillum-plant relationships: environmental and physiological advances (1990-1996). Canadian J ournal of Microbiology, 43: 103-121.

2. Dekhil B, Cahill M, Stackebrandt E \& Sly LI (1997). Transfer of Conglomeromonas largomobilis subsp. largomobilis to the genus Azospirillum as Azospirillum largomobile comb. nov., and elevation of Conglomeromonas largomobilis subsp. parooensis to the new type species of Conglomeromonas parooensis sp. nov. Systematic and Applied Microbiology, 20: 7277.

3. Boddey RM \& Döbereiner J (1995). Nitrogen fixation associated with grasses and cereals: Recent progress and perspectives for the future. Fertilizer Research, 4 : 1-10.

4. Bazzicalupo $M \&$ \& Okon Y (2000). Associative and endophytic symbiosis. In: Pedrosa F, Hungria $M$, Yates MG \& Newton WE (Editors), Nitrogen Fixation: From Molecules to Crop Productivity. Kluwer Academic Publishers, London.

5. Oliveira ALM, Urquiaga S, Döbereiner J \& Baldani JI (2000). Biological nitrogen fixation (BNF) in micropropagated sugarcane plants inoculated with different endophytic diazotrophic bacteria. In: Pedrosa F, Hungria M, Yates MG \& Newton WE (Editors), Nitrogen Fixation: From Molecules to Crop Productivity. Kluwer Academic Publishers, London.

6. Magalhães FM, Baldani JI, Souto SM, Kuykendall J R \& Döbereiner J (1983). A new acid-tolerant Azospirillum species. Anais da Academia Brasileira de Ciências, 55: 417-430.

7. Grifoni $A$, Bazzicalupo $M$, Serio $C D$, Fancelli S \& Fani R (1995). Identification of Azospirillum strain by restriction fragment length polymorphism of the $16 \mathrm{~S}$ rDNA and of the histidine operon. FEMS Microbiology Letters, 127: 85-91.

8. Fani R, Bandi C, Bazzicalupo M, Ceccherini MT, Fancelli S, Gallori E, Gerace L, Grifoni A, Miclaus N \& Damiani G (1995). Phylogeny of the genus Azospirillum based on 16S rDNA sequence. FEMS Microbiology Letters, 129: 195-200.

9. Passaglia LMP, Nunes CP, Zaha A \&
Schrank IS (1991). The nifHDK operon in the free-living nitrogen-fixing bacteria Azospirillum brasilense sequentially comprises genes $\mathrm{H}, \mathrm{D}, \mathrm{K}$, an $353 \mathrm{bp}$ ORF and gene Y. Brazilian J ournal of Medical and Biological Research, 24: 649-675.

10. Frazzon J \& Schrank IS (1998). Sequencing and complementation analysis of the nifUSV genes from Azospirillum brasilense. FEMS Microbiology Letters, 159: 151-158.

11. Döbereiner J , Marriel IE \& Nery M (1976). Ecological distribution of Spirillum lipoferum Beijerinck. Canadian J ournal of Microbiology, 22: 1464-1473.

12. Sambrook J, Fritsch EF \& Maniatis $T$ (1989). Molecular Cloning: A Laboratory Manual. 2nd edn. Cold Spring Harbor Laboratory, Cold Spring Harbor, NY.

13. Schrank IS, Zaha A, Araújo EF \& Santos DS (1987). Construction of a gene library from Azospirillum brasilense and characterization of a recombinant containing the nif structural genes. Brazilian J ournal of Medical and Biological Research, 20: 321330.

14. Sanger F, Nicklen $S \&$ Coulson AR (1977). DNA sequencing with chain-terminating inhibitors. Proceedings of the National Academy of Sciences, USA, 74: 54635467.

15. Liang YY, Kaminski PA \& Elmerich $C$ (1991). Identification of a nifA-like regulatory gene of Azospirillum brasilense Sp7 expressed under conditions of nitrogen fixation and in the presence of air and ammonia. Molecular Microbiology, 5: 2735-2744.

16. Arsène $F$, Kaminski $P A \&$ Elmerich $C$ (1996). Modulation of NifA activity by PII in Azospirillum brasilense: evidence for a regulatory role of the NifA N-terminal domain. J ournal of Bacteriology, 178: 48304838.

17. de Zamaroczy M, Paquelin A, Peltre G, Forchhammer K \& Elmerich C (1996). Coexistence of two structurally similar but functionally different PII proteins in Azospirillum brasilense. J ournal of Bacteriology, 178: 4143-4149.

18. Benelli EM, Souza EM, Funayama S, Rigo LU \& Pedrosa FO (1997). Evidence for two possible glnB-type genes in Herba- spirillum seropedicae. J oumal of Bacteriology, 179: 4623-4626.

19. Passaglia LMP, Schrank A \& Schrank IS (1995). The two overlapping Azospirillum brasilense upstream activator sequences have differential effects on nif $\mathrm{H}$ promoter activity. Canadian J oumal of Microbiology, 41: 849-854.

20. Morett E \& Buck M (1988). NifA-dependent in vivo protection demonstrates that the upstream activator sequence of nif promoters is a protein binding site. Proceedings of the National Academy of Sciences, USA, 85: 9401-9405.

21. de Zamaroczy M, Delorme F \& Elmerich C (1989). Regulation of transcription and promoter mapping of the structural genes for nitrogenase (nifHDK) of Azospirillum brasilense Sp7. Molecular and General Genetics, 220: 88-94.

22. de Zamaroczy M, Delorme F \& Elmerich C (1990). Characterization of three different nitrogen-regulated promoter regions for the expression of glnB and glnA in Azospirillum brasilense. Molecular and General Genetics, 224: 421-430.

23. Fu H, Hartmann A, Lowery RG, Fitzmaurice WP, Roberts GP \& Burris RH (1989). Posttranslational regulatory system for nitrogenase activity in Azospirillum spp. J oumal of Bacteriology, 171: 4679-4685.

24. Elmerich C, Zimmer W \& Vieille C (1991). Associative nitrogen fixation bacteria. In: Stacey G, Evans H \& Burris R (Editors), Biological Nitrogen Fixation. Chapman and Hall, New York

25. de Zamaroczy M (1998). Structural homologues $\mathrm{P}_{\|}$and $\mathrm{P}_{\mathrm{Z}}$ of Azospirillum brasilense provide intracellular signalling for selective regulation of various nitrogendependent functions. Molecular Microbiology, 29: 449-463.

26. Nicholas KB \& Nicholas J r HB (1997). GeneDoc: Analysis and visualization of genetic variation. Available at: http:/www. cris.com/ketcup/genedoc.shtml. ACcessed 1999.

27. Nicholas KB, Nicholas J $r$ HB \& Deerfield DW (1997). GeneDoc: Analysis and visualization of genetic variation. EMB News, 4: 14-14. 